\title{
A História no Mundo \\ Digital: breves \\ considerações sobre \\ as tecnologias \\ digitais e o Ensino de \\ História
}

\section{Renan Carvalho Wenderrosck ${ }^{*}$}

DOI: 10.11606/issn.2318-8855.v10i2p330-359

Resumo: Este trabalho tem como objetivo estabelecer algumas considerações sobre o ensino de história e o uso da tecnologia. Na era da hiperconexão, em um mundo cada vez mais conectado, com o imediatismo pautando as novas relações dos sujeitos, faz-se necessário refletirmos sobre os métodos e instrumentos utilizados na educação e, especialmente, no ensino de História. Desta forma, as ferramentas digitais fornecem potencialidades para a estruturação de uma zona capaz de promover a apreensão dos diferentes contextos históricos e suas temporalidades. Esse artigo é divido em duas partes: a primeira busca compor um breve contexto do Ensino de História no Brasil a partir dos eventos históricos e da historiografia produzida, compreendendo as diferentes influências que se manifestam no atual sistema de ensino. Já a segunda parte busca trazer breves considerações sobre os proveitos e os desafios da utilização das tecnologias digitais no ensino de história a partir da leitura das obras de Pierre Lévy sobre a era digital. Se "ensinar não é transmitir conhecimento, mas criar as possibilidades para sua própria construção" (FREIRE, 1996, p. 21), sem a menor dúvida, as ferramentas digitais podem ajudar a construir novos caminhos a serem utilizados no processo de escolarização dos indivíduos.

Palavras-chaves: Consciência Histórica; Ensino de História; Tecnologias Digitais.

\footnotetext{
* Graduando em História e bolsista PIBIC-CNPq pela Universidade Federal Fluminense e Bolsista PIBICCNPq pela UFF - e-mail: renanwcarvalho@gmail.com.
}

Gostaria de agradecer a Prof. ${ }^{a}$ Dr. ${ }^{a}$ Maria Fernanda Bicalho pelo carinhoso apoio e incentivo recebido e a Carolina Manhães pelo suporte no pouco tempo que lhe coube, pelas suas correções e conselhos. 


\section{artigos}

\section{A História no Mundo Digital}

\section{Introdução}

Eu quero entrar na rede

Promover um debate

Juntar via Internet

Um grupo de tietes de Connecticut

É inegável a presença do meio digital no nosso dia a dia. A internet e as funções que ela compreende se tornaram parte da nossa realidade e das nossas novas formas de comunicação. O trecho acima foi retirado da canção "Pela internet" do cantor e compositor Gilberto Gil, onde fica claramente evidente a grande rede de comunicação que foi estabelecida, e que liga diferentes partes e locais pelo mundo. Ao "entrar na rede", o usuário pode se conectar "aos lares do Nepal”, "os bares do Gabão" ou até mesmo promover um debate com "um grupo de tietes de Connecticut", ações possíveis neste contexto virtual. A World Wide Web, rede mundial de computadores e internet que se popularizou a partir de 1991, se consolidou nos últimos anos e se tornou elemento básico para a sociedade contemporânea do século XXI. Sociedade esta que virtualizou suas relações no espaço digital.

Os avanços tecnológicos atuais são constantes, o que torna cada vez mais impossível manter a educação atualizada. Com o desenvolvimento das novas Tecnologias de Informação e Comunicação - TIC, alterou-se a forma que lidamos com a informação e com o conhecimento. O antigo modelo de ensino e aprendizagem tradicional, que ainda possui fortes influências na forma como são desenvolvidos os conhecimentos pedagógicos, não supre totalmente as demandas dos tempos atuais. Para alterar esta conjuntura, faz-se necessário um urgente diagnóstico e reconhecimento 


\section{artigos}

\section{Renan Carvalho Wenderrosck}

das ambivalências e contradições presentes na atual educação básica. Somente através deste caminho poderemos ressignificar as tecnologias digitais, buscando elaborar novos instrumentos didáticos que absorvam a nova realidade do estudante da "geração Z".

Este trabalho tem como objetivo estabelecer algumas considerações sobre o ensino de História e o uso da tecnologia. Na era da hiperconexão, em um mundo cada vez mais conectado, com o imediatismo pautando as novas relações dos sujeitos, faz-se necessário refletirmos sobre os métodos e instrumentos utilizados na educação e, especialmente, no ensino de História. Se "ensinar não é transmitir conhecimento, mas criar as possibilidades para sua própria construção" (FREIRE, 1996, p. 21), sem a menor dúvida, as ferramentas digitais podem ajudar a construir novos caminhos a serem utilizados no processo de escolarização dos indivíduos.

Desta forma, busco neste artigo dissertar de forma inicial sobre como podemos pensar as ferramentas digitais no ensino de História, assim como as contribuições das tecnologias digitais dentro dos processo de ensino e aprendizagem. Ainda que não pretenda fazer uma extensa revisão historiográfica sobre as produções acerca dessas duas temáticas, defendo que as potencialidades dos usos dessas ferramentas fornecem elementos para a estruturação de uma zona capaz de promover a apreensão dos diferentes contextos históricos e das suas temporalidades.

Assim sendo, este artigo é fruto de reflexões sobre as práticas de ensino e sobre o contexto social vivido atualmente. Situo-me no meu quadrante de estudante de graduação, o que poderá ser observado ao longo deste artigo. Se os leitores que a partir dessa análise se julgarem bem informados ou cogitarem contribuições e críticas, terei obtido êxito. 


\section{artigos}

A História no Mundo Digital

Para esse artigo, destaca-se a linguagem digital, de acordo com Lévy (1996), em relação aos pressupostos oferecidos nos espaços e ferramentas da tecnologia da informação. É relevante pontuar que o intuito deste trabalho é pensar as potencialidades do ambiente virtual na construção dos conhecimentos pedagógicos, desenvolvidos através de programas e aplicativos específicos. O foco não está especificamente no contexto de espaço da Cibercultura - onde, segundo Lévy (1999), há “um fluxo contínuo de ideias, práticas, representações, textos e ações que ocorrem entre pessoas conectadas por computadores" - mas em como o espaço virtual tecnológico pode ser uma ferramenta educacional.

Considerando os atuais contextos de escolarização, sabendo que a História é constituída a partir dos problemas postos no presente, de que forma o ambiente virtual digital vem a contribuir na formação dos novos estudantes em relação à disciplina História? Como podemos pensar o sistema educacional a partir das transformações sociais e da assimilação da nova cultura digital? Com o intuito de refletir sobre essas questões, o artigo está dividido em dois movimentos. O primeiro busca estabelecer uma breve história da instrução pública no Brasil, especialmente no campo do ensino de História, a partir do século XIX. Em um contexto de circulação de ideias e de uma proposta de sociedade fundadas na modernidade, resgatarei algumas correntes de pensamento hegemônicas desde o século XVIII, como o Positivismo e o Historicismo, que ajudam a pensar a Educação nestas terras dos trópicos. Faz-se necessário olharmos para a história do ensino público, assim como para a historiografia do ensino da História, a fim de compreendermos as diferentes influências que se manifestam no atual sistema de educação. 


\section{artigos}

\section{Renan Carvalho Wenderrosck}

Em relação à segunda parte, traçarei breves considerações sobre os desafios na utilização das tecnologias digitais no ensino de História. Valendo-nos das abordagens de virtualização do conhecimento histórico, assim como da criação de plataformas on-line, é possível pensarmos em novas condições para a criação de uma cultura escolar mais atual, consciente da sua missão cidadã. Desta forma, considero que o ambiente virtual pode, efetivamente, ser um espaço de comunicação com o mundo dos estudantes, assim como um meio de acesso ao passado que, por vezes, é visto como distante e remoto, sem o menor vínculo com o momento presente.

\section{A História do ensino de História: elementos em perspectiva}

O campo da disciplina História foi marcado até recentemente pelo estudo do passado como elemento de construção memorialista. Um estudo mnemônico sobre um passado criado para sedimentar uma origem branca e cristã, frequentemente corroborando e justificando as tradições inventadas ao longo da história do Brasil nos últimos dois séculos. Atualmente, esta condição vem sendo questionada (BITTENCOURT, 2018, p. 127).

A incorporação de novos sujeitos como agentes históricos e a observância de novas temporalidades históricas contra um ensino monocausal e teleológico parecem compor um novo modelo de educação histórica para os novos tempos. A história do Ensino de História no Brasil é marcada por diferentes momentos que refletem o campo das ideias e das práticas políticas contemporâneas a tais épocas. À guisa de exemplo, o ensino de História durante o Império possuía objetivos próprios e diferentes da educação no século XXI. Desta maneira, desde o estabelecimento do campo da disciplina História a partir de 1838, no renomado Colégio Pedro II na capital do império, 


\section{artigos}

A História no Mundo Digital

muitos projetos políticos disputaram entre si, a fim de se estabelecerem como hegemônicos.

Apesar de não se encontrar registros sobre a existência da disciplina de História antes de 1838 (MANOEL, 2012), a ausência de uma matéria escolar não é sinônimo da ausência dos conteúdos históricos na história da instrução pública no Brasil. Ainda que sob diferentes objetivos e formas, os conteúdos históricos fizeram parte dos estudos das Humanidades Clássicas nas escolas dos jesuítas dos séculos XVI ao XVIII. Desde o início do processo de colonização do Brasil, a instrução pública ficou sob a tutela da Igreja Católica, perdurando, estruturalmente, até a proclamação da República.

Nos colégios jesuíticos, instalados na colônia, eram difundidos os diferentes textos "clássicos", entendendo as Humanidades Clássicas como "formação originária dos antigos romanos e gregos" que visavam oferecer uma preparação do "indivíduo para ser homem em toda a plenitude do seu sentido" (CHERVEL; COMPÈRE, 1999, p.150). Desde o princípio da colonização e o estabelecimento do sistema confessional de educação da Companhia de Jesus, poucos elementos foram alterados, e uma mudança estrutural veio apenas com as reformas ocorridas nos meados do século XIX, encabeçadas pelo Império do Brasil.

A criação do Colégio Pedro II teve a intenção de fundar um modelo de estrutura para um ensino secundário mais abrangente e organizado (MANOEL, 2012, p. 1). Após os movimentos de independência do Brasil ocorridos em 1822, a identidade lusobrasileira construída nos anos coloniais já não servia mais, o que tornou necessário a criação de novas bases para o Estado Imperial Brasileiro, convertendo as "nações" em uma nação brasileira. Em tempos de processo de independência, tão marcados por 


\section{artigos}

\section{Renan Carvalho Wenderrosck}

revoltas populares e fissuras institucionais, era preciso criar continuidades a partir de rupturas, inventando assim tradições que justificassem a origem de um povo brasileiro uníssono e uniforme.

Para Hobsbawm (1997), a invenção das tradições ocorre quando há a necessidade de adaptação de velhos costumes em condições novas, assim como usar velhos modelos para novos fins. Esse processo se constrói através da utilização de elementos antigos para dar condições à elaboração de novas tradições com fins bastante originais, caracterizado pela continuidade bastante superficial do passado em relação ao presente.

Dois pontos iniciais devem ser imediatamente discutidos: A estreita relação entre o Colégio Pedro II e o Instituto Histórico Geográfico Brasileiro, assim como sua proximidade com a Igreja Católica. Por um lado, o colégio foi criado com o objetivo de atender a demanda da instrução pública dos diferentes indivíduos da alta sociedade do Rio de Janeiro, sendo que os conhecimentos transmitidos aos alunos eram elaborados e pesquisados através da atuação do IHGB. Desta forma, segundo Bittencourt, a constituição da História sob a forma de uma disciplina autônoma incluía "uma fundamentação sustentada nas relações entre o conteúdo e o método de ensinoaprendizagem", absorvida dessa comunicação entre IHGB e CPII.

Conforme indicado por Manoel Salgado Guimarães, esses indivíduos também circulavam nas esferas do poder do Estado Brasileiro, contribuindo para a construção do país em questões estruturais, assim como nas questões ideológicas (GUIMARÃES, 2011, p. 229-258).

Nesta forma de ensino tradicional elaborada nos anos do Império a partir da fundação do CPII, nota-se uma forte influência das correntes teóricas francesas, como 


\section{artigos}

A História no Mundo Digital

o Historicismo, buscando uma construção de história positiva definida a partir de bases científicas para a pesquisa histórica. O historicismo inaugura uma nova visão para a observação da História como Ciência Moderna ${ }^{1}$, propondo principalmente as pretensões pedagógicas das disciplinas científicas como orientação do presente, assim como a concepção sobre as diversas histórias particulares como composição da História Universal da Civilização.

Ao pensarmos o contexto da primeira metade do século XIX no Brasil, a Escola Metódica constituiu forte influência na nossa História Nacional. É esta História Científica Metódica que, buscando as raízes do Brasil, exaltará o povo e suas conquistas históricas, construindo retrospectivamente os ideais de unidade nacional e de continuidade histórica que se buscavam na época. Destaca-se a atuação proeminente dos estudos de Francisco Adolfo Varnhagen sobre a História do Brasil, que constitui-se como pedra angular dentro do processo de construção da nação.

Para Guimarães (2011), é parte do quadro histórico do autor a existência das raízes de uma "brasilidade" já no século XVII, algo que, segundo Varnhagen (1877), apresentou-se na luta contra as tropas coloniais holandesas. Desta forma, ao finalizar o primeiro volume da História Geral com a expulsão dos holandeses, o autor define as bases do sentimento nacional brasileiro, isto é, define a história da nação em desenvolvimento. A independência do Brasil, portanto, se define como o resultado do protagonismo do "espírito do povo brasileiro" em relação aos desejos da Coroa de Portu-

\footnotetext{
1 Para Bourdé e Martin, o método científico desenvolvido pela Escola Metódica se baseava em três principais princípios na formulação da pesquisa histórica: A crítica externa de Erudição, A crítica interna (ou heurística); e por último, as operações sintéticas (comparação de documentos para estabelecer um fato particular e posteriormente inseri-lo, quer por dedução ou por analogia, em quadros gerais). Ver mais em BOURDÉ, Guy; MARTIN, Hervé. "A escola metódica" In As Escolas Históricas. Portugal: Publicações Europa-América, 1983, p. 97-118.
} 


\section{artigos}

\section{Renan Carvalho Wenderrosck}

gal, fruto de um longo processo de amadurecimento e evolução. Nesta lógica, o sucesso adveio das condições do processo civilizador empregado no Brasil, ou seja, da miscigenação das três raças: os europeus, os indígenas e os negros. Ironicamente, o sucesso do processo de miscigenação deste povo não atribuiu glória e reconhecimento heroico às figuras de liderança indígenas e africanas, mas somente a representantes europeus "civilizados", sedimentando um modelo de história branca e cristã.

No redemoinho de tensões e incertezas que circulavam o recém-criado Estado do Brasil, a instituição do Colégio Pedro II e do IHGB cumpriam uma tarefa política fundamental, construindo uma Nação una e harmoniosa, soldando as fissuras existentes entre as províncias e a mãe pátria de todos os brasileiros - ou pelo menos aqueles que fossem considerados brasileiros pela Constituição de 1822.

Seguindo para o final do século XIX, com os novos ares da República e o fruto de rupturas estruturais políticas e ideológicas em relação à Monarquia, o conjunto de ideias positivistas assumiu protagonismo histórico com a Proclamação da República. O sucesso alcançado pelos escritos de Augusto Comte nas suas formulações sobre o positivismo alcançou hegemonia nos campo das ideias filosóficas europeias. O sucesso foi tamanho que, por volta de 1870 , muitas classes abastadas da sociedade brasileira do final do Império mandariam seus filhos para as escolas europeias a fim de receber uma educação requintada, o que, no contexto cultural da época, não poderia existir nas escolas brasileiras. Era, portanto, uma educação extremamente elitista (OLIVEIRA, 2010, p. 9).

É inegável a participação das ideias positivistas nos processos de proclamação da República no Brasil. Basta olharmos a bandeira nacional e veremos o importante lema dos positivistas indicando a ordem e o progresso para o desenvolvimento da 


\title{
artigos
}

A História no Mundo Digital

nação rumo ao curso da marcha teleológica do progresso e do desenvolvimento científico.

Em relação ao campo político, o positivismo forneceu inexoravelmente os ideais necessários para a afirmação social da pequena burguesia emergente, principalmente em relação às transformações industriais, que marcariam o sucesso da evolução dos três estágios definidos pela teoria de Comte. Sendo assim, esses intelectuais contribuíram diretamente com instrumentos ideológicos contra quaisquer amarras que pudessem "frear" o processo de modernização da sociedade brasileira no início da República (OLIVEIRA, 2010, p. 15). Desta forma,

\begin{abstract}
A introdução da "civilização" e do "progresso" como conceitos fundamentais no ensino de História sofreu contestações por parte de professores e historiadores, mas tais conceitos foram sendo incorporados e consagrados pela elite nacional renovada no período republicano pelos novos "donos do poder", idealizadores da política "café com leite". [...] A modernização do Brasil estava ainda em fase inicial e difundia-se a ideologia do "país do futuro" de acordo com a noção do tempo histórico evolutivo e do progresso impossível de ser violado (BITTENCOURT, 2018, p. 136).
\end{abstract}

No campo dos instrumentos pedagógicos utilizados no ensino de História, houveram poucas mudanças, mantendo um ensino baseado em manuais escolares sobre a longa história da civilização brasileira inserida na História Universal. Um ensino estritamente estruturado de forma linear e factual, desenvolvido em uma pedagogia de aulas expositivas, valorizando a memorização dos alunos de verdades vistas como absolutas e irrefutáveis. As propostas curriculares e os manuais escolares que se difundiam nas primeiras décadas republicanas mantinham, em essência, "o método catequético do humanismo clássico com as práticas do 'aprender de cor' as causas e os efeitos dos diferentes acontecimentos" realizados pelos heróis da História (BITTENCOURT, 2018, p. 136). 


\section{artigos}

\section{Renan Carvalho Wenderrosck}

Portanto, é principalmente esta corrente que fundará os heróis nacionais e os grandes homens da História, utilizando-se especialmente dos diferentes elementos históricos. Nesta lógica, o ensino desse modelo de História contribuiu diretamente para a criação quase que indelével da História dos Vencedores e do Ensino Tradicional que ainda influenciam, por vezes, os atuais currículos e diretrizes para a Educação Nacional.

A História Metódica, com construção nacionalista, ainda faz parte do nosso imaginário social brasileiro, sendo atuais as reflexões em relação a esses paradigmas históricos, em ambientes formais e não formais de escolarização. Sem a menor dúvida, sabemos mais sobre "as conquistas" feitas por Pedro Alvarez Cabral do que os cotidianos de resistência em Palmares.

A consolidação do ensino de História da Civilização em escala nacional se firmou através das determinações da Reforma de Francisco Campos de 1931, sem ao menos propor grandes críticas ao então presente modelo. Pouco se avançou nas estruturas construídas ao longo da Primeira República. Até a década de 1930, o acesso à educação de forma geral estava restrito aos filhos das elites governantes que colocavam seus filhos nas escolas particulares das diferentes capitais do país. A demora na tomada de decisão no campo educacional levou alguns educadores a assinarem, em 1932, o Manifesto dos Pioneiros da Educação Nova, conceito emergente dos reformadores da educação desde a década de 1920, influenciados por correntes da biologia e da psicologia dos Estados Unidos.

No campo legal, a Constituição de 1934 inaugurou grandes avanços na construção de uma educação nacional como direito de todos e dever do Estado. Sendo a primeira constituição a pensar em um plano nacional para a educação, construiu um 


\section{artigos}

\section{A História no Mundo Digital}

aparato sistêmico e organizado para o ensino popular, ainda que já tivessem ocorrido algumas reformas educacionais em âmbito estadual. No campo pedagógico, pouca coisa mudou tendo em vista que se ratificavam em lei as obrigações cívicas e patrióticas da nação brasileira, valorizadas ainda mais a partir de 1937, na consolidação do Estado Novo.

As grandes reformas estruturais no Ensino de História se deram a partir da década de 1950 e 1960. A criação de cursos de história em centros universitários a partir dos anos de 1950 intensificou a preocupação com a formação de professores. Esses deveriam buscar o desenvolvimento de pesquisas no campo científico da História, assim como a revisão dos antigos paradigmas historiográficos do ensino básico.

Com o alargamento do acesso à educação básica, os princípios de industrialização e conhecimentos fundamentais da sociedade contemporânea industrial, a educação, por fim, deveria inovar seus métodos e práticas de ensino.

Na década de 1950, com os avanços tecnológicos e industriais desenvolvidos na sociedade do século XX, desenvolveram-se novos instrumentos para a educação dos trabalhadores e para o ensino técnico. As teorias da Escola Nova, que outrora pensara os sistemas de educação na relação aluno-sistemas de aprendizagem diferentes da "transmissão de conhecimento professor-aluno" do Ensino tradicional, já não davam mais conta de solucionar os problemas da educação básica. O escolanovismo foi o movimento que resultou na tentativa de superação da escola tradicional e da relação de transmissão de conhecimento professor-aluno, modelo excessivamente rígido, magistrocêntrico e voltado para a memorização dos conteúdos. Esse projeto pensava a educação através de métodos ativos, com mais ênfase nos processos do conhecimento que propriamente no produto. Para tanto as atividades seriam centradas nos 


\section{artigos}

\section{Renan Carvalho Wenderrosck}

alunos, e a criação de laboratórios, oficinas, hortas ou até imprensa, faziam parte do espaço escolar escolanovista sendo capaz de desenvolver diferentes habilidades nos estudantes (ARANHA, 2006, p. 424).

A partir da década de 1970, com a emergência do tecnicismo no Brasil, houve uma transformação nos processos de aprendizagem. Passando a priorizar as tecnologias de ensino em detrimento dos conteúdos acadêmicos e escolares, as formulações para o ensino e para o espaço escolar mudaram drasticamente. A valorização dos pressupostos da neutralidade científica e as inspirações nos princípios da racionalidade, eficiência e produtividade, contribuíram para a consolidação de uma pedagogia que buscava defender o processo educacional a partir daquilo que era objetivo, racional e operacionalizado em etapas (CAIMI, 2007, p. 27).

Deste modo, semelhante ao trabalho fabril, pretendia-se a objetivação do trabalho pedagógico.

Com efeito, se no artesanato o trabalho era subjetivo, isto é, os instrumentos de trabalho eram dispostos em função do trabalhador e este dispunha deles segundo seus desígnios, na produção fabril essa relação é invertida. Aqui, é o trabalhador que deve se adaptar ao processo de trabalho, já que este foi objetivado e organizado na forma parcelada. Nessas condições, o trabalhador ocupa seu posto na linha de montagem e executa determinada parcela do trabaIho necessário para produzir determinados objetos. O produto é, pois, uma decorrência da forma como é organizado o processo (SALVIANI, 2008, p. 10).

Operacionalizar os objetivos, mecanizar os processos são tarefas para o desenvolvimento do produto "educação". Dá-se então a proliferação de propostas pedagógicas tais como o enfoque sistêmico, com padronizações do sistema de ensino e esquemas de planejamento previamente formulados aos quais deviam ser ajustados às diferentes disciplinas e conteúdos pedagógicos. Na pedagogia tecnicista, “o elemento principal passa a ser a organização racional dos meios, ocupando o professor e o alu- 


\section{artigos}

A História no Mundo Digital

no posição secundária, relegados que são à condição de executores de um processo", no qual a concepção e planejamento ficam a cargo de especialistas habilitados e imparciais (SALVIANI, 2008, p. 11).

Em relação ao campo do ensino de História ao longo do Regime Militar Brasileiro (1964-1985), as disciplinas de História e Geografia passaram a ser tratadas de modo pragmático, assumindo função exclusiva de legitimação do modelo político vigente. Sendo substituídas pela disciplina de "Estudos Sociais", dividiam a carga horária com a disciplina de "Educação Moral e Cívica”, e "Organização Social e Político Brasileira" no segundo grau (PERES; SCHIRMER; RITTER, 2015, p. 205).

Ao final do século, com os processos de redemocratização, a função do historiador e a História como disciplina tomam novos contornos. Os currículos produzidos após a Lei de Diretrizes e Bases de 1996, assim como as propostas dos Parâmetros Curriculares Nacionais de 1998, dão outras formas para os níveis da educação básica, valorizando principalmente a formação de uma cidadania democrática. A grande virada da educação pública se deu a partir da década de 1990 ao trazer à tona as diferentes narrativas históricas seguindo os alvoreceres da Constituição "Cidadã".

A partir da "Nova História Política" elaborada pela historiografia francesa e absorvida na perspectiva nacional pelas propostas da LDB, foi possível a inclusão de novos sujeitos históricos na cena pública e no direito à cidadania plena. A construção da Base Nacional Comum Curricular, prevista na LDB de 1996, foi finalizada e contém orientações sobre os conteúdos para o Ensino Básico e as competências a serem desenvolvidas pelo campo da disciplina História. Voltado a resposta das questões do presente, o estudo da História na educação básica tem como objetivo abranger as diferentes narrativas históricas na formação da História do Brasil. A superação da 


\section{artigos}

\section{Renan Carvalho Wenderrosck}

longa duração da História Nacional ainda não foi alcançada, sendo preciso ser concluída tanto no ambiente escolar, quanto nos espaços de escolarização informais. Nessa missão, as tecnologias digitais podem servir como instrumento na formulação de novas propostas de ensino orientadas por um projeto que compreenda a diversidade dos agentes históricos, assim como as múltiplas temporalidades presentes no campo da História. A capacidade de virtualização do saber e o uso da interatividade são algumas potencialidades que serão trabalhadas neste segundo movimento do artigo.

\section{O mundo digital: potencialidades para o Ensino de História}

O campo do ensino de História foi construído ao longo de muitas décadas e com diferentes composições históricas. A relação entre a Escola e a Sociedade se estabeleceu de forma dialética desde o início da modernidade, consolidada desde os princípios de cidadania desenvolvidos pela Revolução Francesa e as necessidades geradas pelas Revoluções Industriais.

Por essa imbricação, os métodos educacionais são frequentemente definidos pelo desenvolvimento das tecnologias dentro da sociedade. A passagem do tempo e a alternância das condições culturais geram novas demandas de reflexão e aprendizagem e, neste caso, dos objetivos da aprendizagem do Ensino de História.

É nessa frequente atualização dos métodos a serem aplicados no ambiente escolar, abarcando as novas historiografias produzidas, que se constroem novas pontes de conhecimento entre professores e alunos. Observa-se, então, que o objetivo da educação e do ensino de História não deve ser mais tratado como um ensino mecânico com memorização de datas históricas e elementos factuais, mas deve contemplar os processos históricos com múltiplas narrativas e temporalidades, inserindo o aluno 


\section{artigos}

A História no Mundo Digital

como agente de aprendizado e não como receptor de elementos previamente dados, garantias mínimas definidas na atual Lei de Diretrizes e Bases da Educação².

As ferramentas digitais, através da virtualização do conhecimento, podem ajudar na superação da lógica dos paradigmas do ensino tradicional. As tecnologias não são uma invenção da modernidade ou mesmo das últimas décadas do século XX. Compreende-se aqui como tecnologias as diferentes técnicas empregadas no desenvolvimento humano, desde o arado a boi da Idade Média até as máquinas industriais provenientes da Revolução Industrial. Essas técnicas foram produzidas em acordo com a cultura histórica nas diferentes temporalidades, sendo um dos elementos que compõem as características de uma determinada sociedade.

Em consonância com Levy, não podemos pensar as técnicas como vindas de outro mundo, um lugar frio e sem emoção, ou mesmo um projétil acertando o alvo (a cultura, no caso). As tecnologias são concebidas a partir das interações sociais, compondo um dos elementos do desenvolvimento das sociedades. Consequentemente, a técnica não existe de maneira independente, com vontade própria e sem relação com outras esferas da realidade. Não se pode separar em categorias diferentes as técnicas, a cultura e a sociedade, já que estas compõem o todo e se articulam de forma concomitante e interligada. Os indivíduos habitam um ambiente material e desenvolvem signos e imagens como forma de atribuir sentido a sua vida e ao seu mundo, assim como "inventam, produzem e utilizam objetos técnicos na transformação da sua realidade vivida". Para Levy, a separação só pode ser conceitual, sendo preciso observar as tecnologias consonantes ao tempo em que foram produzidas (LEVY, 1999, p. 21-22).

\footnotetext{
${ }^{2}$ LDB 9.394 - Lei de Diretrizes e bases da Educação. Seção I, art. 22
} 


\section{artigos}

\section{Renan Carvalho Wenderrosck}

Assim como as tecnologias não são invenções do mundo contemporâneo, os processos de virtualização seguem a mesma lógica. Segundo Levy, o conceito de 'virtual' pode ser compreendido de três formas diferentes: a primeira se define a partir de uma concepção filosófica; a segunda, por meio do uso corrente; e a terceira pelas concepções informacionais. Neste trabalho, o foco será na sua concepção filosófica.

Na acepção filosófica de Levy, "é virtual aquilo que existe apenas em potência e não em ato, o campo de forças e de problemas que tende a resolver-se em uma atualização" (LEVY, 1999, p. 47). Define-se como o estado antes da concretização efetiva ou mesmo formal - o autor cita o exemplo no qual a árvore se encontra virtualmente presente no grão. Desta forma, é a capacidade de existência de uma concepção apenas em potência ou em faculdade, e não faz oposição ao real. Assim, para Levy, "virtualidade e atualidade são apenas duas maneiras de ser diferentes" (LEVY, 1996, p. 5). Essa ideia é pouco utilizada cotidianamente já que frequentemente observamos seu uso para concepções em oposição à materialidade das coisas reais e físicas.

Para Levy, é virtual toda entidade "desterritorializada", capaz de gerar diversas manifestações concretas em diferentes momentos e locais determinados, sem estar presa a um determinado lugar. Utilizamos frequentemente este processo cognitivo ao longo da nossa comunicação, tendo em vista que as palavras pertencem ao campo do virtual e as tornamos "atuais" a partir do seu uso. O que se entende, portanto, é que “a palavra em si, aquela que é pronunciada ou atualizada em certo lugar, não está em lugar nenhum e não se encontra vinculada a nenhum momento em particular (ainda que ela não tenha existido desde sempre)" (LEVY, 1999, p. 48).

Desta forma, a virtualização e o virtual não surgiram com o advento da Internet, mas sim, compõem parte do desenvolvimento humano e das suas formas de comuni- 


\title{
artigos
}

A História no Mundo Digital

cação. O autor demonstra que "ao analisar os desenvolvimentos da linguagem, da técnica e das instituições sociais complexas, a espécie humana se construiu pela virtualização". A capacidade de abstração compõe elementos da virtualização dentro dos processos cognitivos (LEVY, 1999, p. 135).

\begin{abstract}
Repetindo, ainda que não possamos fixá-lo em nenhuma coordenada espaçotemporal, o virtual é real. Uma palavra existe de fato. O virtual existe sem estar presente. Acrescentemos que as atualizações de uma mesma entidade virtual podem ser bastante diferentes umas das outras, e que o atual nunca é completamente predeterminado pelo virtual. [...] Nenhuma atualização da palavra se parece exatamente com nenhuma outra, e há pronúncias (nascimentos de novas vozes) ou sentidos (invenções de novas frases) imprevisíveis que, no entanto, podem sempre aparecer. O virtual é uma fonte indefinida de atualizações (LEVY, 1999, p. 48).
\end{abstract}

Portanto, qual seria a diferença entre o digital e o virtual? Conforme Levy (1999, p.39), o digital se define como o "conjunto de possíveis que, mesmo podendo ser imenso, ainda assim é numericamente finito e logicamente fechado", como por exemplo, os suportes digitais que têm seus dados armazenados em unidades de armazenamento finitos. O digital é fechado e não complexo. Já em relação ao virtual, Levy ressalta que 0

virtual só eclode com a entrada da subjetividade humana no circuito, quando num mesmo movimento surgem a indeterminação do sentido e a propensão do texto a significar, tensão que uma atualização, ou seja, uma interpretação resolverá na leitura (LEVY, 1999, p. 40).

Desta forma, o virtual pode ser compreendido como algo dinâmico, do vir a ser, ao seu uso da potencialidade proposta pelos seus significados filosóficos. Sendo assim, a complexidade só existe pela interação entre humanos e máquinas, e não apenas entre tecnologias digitais - ou seja, um objeto virtual se manifesta através de um suporte, no qual "se torna" presente a partir do seu ato de atualização. 


\section{artigos}

\section{Renan Carvalho Wenderrosck}

Como pontuado anteriormente, a virtualização é um dos principais vetores da criação da realidade dos conhecimentos desprendidos do aqui e do agora. A imaginação, a memória, o conhecimento, a religião são vetores de virtualização que nos fazem abandonar a materialidade muito antes do advento da era da informação e das redes digitais. Logo, o virtual se define como esse "lugar" que não é presente, mas que existe em sistemas de registro e de transmissão pautados por ritmos, velocidades ou mesmo pontos de experiência diferentes baseados na experiência daquele que se atualiza.

As ferramentas digitais são compostas por esses espaços virtuais nos quais os conhecimentos são armazenados, ainda que não haja materialidade direta, e que podem ser atualizados frequentemente com novas definições e formulações. Estas ferramentas digitais e sua capacidade de virtualização através das plataformas digitais podem oferecer recursos refinados nos processos de construção da consciência histórica. Se a leitura nos leva para outros lugares, sem a menor dúvida, o uso adequado das tecnologias digitais no campo do ensino de História podem criar pontes entre o passado e o presente, integrando alunos e professores momentaneamente na construção do conhecimento histórico, e, acima de tudo, na construção dos saberes escolares.

Segundo Levy, a tecnologia digital frequentemente exterioriza, objetiva, e virtualiza uma função cognitiva (no sentido de categorizar, organizar, sistematizar, classificar, temporalizar, etc.) na elaboração de uma atividade mental, isto é, as ferramentas digitais podem servir como grande auxílio na formulação das noções históricas que se busca fundar na educação básica. Desta maneira, como aponta Freitas, o emprego de diferentes métodos, entendidos como caminhos, “dependem necessariamente das 


\section{artigos}

A História no Mundo Digital

finalidades concebidas pelo professor para o ensino da disciplina e estão relacionados aos conteúdos históricos com os quais se vai trabalhar" (FREITAS, 2010, p. 216).

Aqui, portanto, avalia-se os métodos digitais, tendo dois pontos a serem destacados. O primeiro ponto diz respeito à elaboração da ferramenta digital e o seu uso dentro de sala de aula. Como já descrito por Levy, as tecnologias digitais são as ferramentas para a construção de um momento dentro da sala de aula, e não devem ser usadas com a finalidade de processos de ensino-aprendizagem, princípios valorizados pelas concepções tecnicistas da década de 1970. Os processos tecnológicos não devem estar acima dos pressupostos para a construção do conhecimento histórico, mas devem servir como caminhos para sua concretização, intermediando as relações entre professores e alunos, negociando os espaços.

Defendo neste quesito que as ferramentas digitais de virtualização do conhecimento devem servir como intermediadores entre o mundo dos conhecimentos históricos, muitas vezes considerados distantes e apartados da realidade em relação ao mundo dos estudantes, que é ativo e dinâmico, fruto dos avanços dos sistemas de tecnologia da informação.

O meio digital deve ser utilizado como espaço de troca e acesso às possíveis realidades do passado, em um processo de ambientação dos contextos históricos e das diferentes narrativas históricas através dos processos virtuais que essas ferramentas oferecem. Assim, o espaço virtual elucida a História servindo de suporte na construção dos conhecimentos históricos, assim como de suas historicidades, contribuindo na formação escolar dos futuros cidadãos já que pode abarcar a diversidade dos sujeitos históricos que a história compõe. 


\section{artigos}

\section{Renan Carvalho Wenderrosck}

É neste espaço virtual que pode ser criada uma unidade de tempo e espaço para atualização dos conceitos históricos, assentando um trabalho em potência, assim como gerando outras condições para o desenvolvimento das unidades cognitivas. Se antes o aluno apresentava dificuldades de se "transportar" para o tempo e contexto histórico específico da aula, agora ele pode observar, interagir e imergir nesse ambiente, permitindo-o a desenvolver capacidades e raciocínios a partir da sua experiência, ainda que esse mundo não seja real.

Essa habilidade pode ser trabalhada de forma breve em sala de aula a partir de um programa de realidade aumentada no qual o aluno, dotado de seu celular e circulando pelos espaços da própria sala de aula, consegue, por exemplo, "desbravar" o Largo do Paço no Rio de Janeiro em 1808. Esse aluno pode observar os sujeitos históricos que ali circulavam, assim como, as características patrimoniais através da tela do seu celular. Previamente, as abstrações históricas ficavam restritas a imagens iconográficas ou ao exercício da imaginação, neste momento, entretanto, o mundo digital pode aperfeiçoar as experiências com o passado, bem como os processos de construção da consciência histórica.

Isso nos dá condições de pensarmos o segundo aspecto: a interatividade dos jogos e dispositivos didáticos para o campo do Ensino de História. Segundo Levy, a interatividade é o fenômeno que acontece quando há participação ativa do beneficiário em uma transação de informação. Um indivíduo assistindo a televisão, comunicando-se por telefone celular ou até mesmo por videochamadas representam diferentes formas de interatividade.

Nesta definição, "a possibilidade de reapropriação e de recombinação do material da mensagem por seu receptor é um parâmetro fundamental" (LEVY, 1999, p. 79) 


\section{artigos}

A História no Mundo Digital

para avaliar o grau de interatividade de um determinado equipamento. Para o autor, o telefone celular é uma das mídias mais interativas já que permite o diálogo, a reciprocidade e a comunicação efetiva, ao passo que a televisão, mesmo digital e navegável, possui menos interatividade por possuir apenas um espetáculo a oferecer.

A interatividade pode ser estabelecida tanto por uma relação entre indivíduos, quanto por um sujeito e uma matriz de informação, como no caso dos videogames. De qualquer forma, sempre haverá dois entes da comunicação. A diferença é que, neste último caso, o modelo é “capaz de gerar uma quantidade quase infinita de 'partidas' ou de percursos diferentes (mas todos coerentes)" (LEVY, 1999, p. 80). Aqui, a interatividade remete ao virtual. É “a imagem modificada do personagem reatualizado que modifica em um segundo tempo lógico, o próprio espaço do jogo". Para envolverse de verdade, "o jogador deve projetar-se no personagem que o representa e, portanto, ao mesmo tempo, no campo de ameaças, ações e oportunidades em que vive no mundo virtual comum" (LEVY, 1999, p. 80). Desta forma, ao jogar, o usuário envia a seu parceiro outra imagem de si mesmo e de seu mundo comum, imagem que é absorvida pelo parceiro de jogo, afetando o seu modus operandi imediatamente.

Tendo isso em vista, a interatividade das ferramentas digitais pode contribuir diretamente para a construção de jogos cooperativos que podem ser utilizados dentro de sala de aula no campo da disciplina História: RPG (Role Playing Game, em português "jogo de interpretação de papéis"), multiusuários em uma rede particular de acesso, videogame em "realidade virtual" com vários participantes, comunicação em mundos virtuais ou mesmo um espaço de negociação contínua dos participantes sobre suas funções em uma situação comum podem constituir o espaço interativo digital dentro de uma sala de aula. Os alunos, desta forma, não se encontram apartados 


\section{artigos}

\section{Renan Carvalho Wenderrosck}

em seus celulares, manipulando individualmente a atividade, mas precisam se ajustar e se adequar, em grupo, buscando melhores respostas e melhor desenvolvimento dentro da interface.

A interatividade incita outros caminhos na construção dos conhecimentos ao estabelecer dinâmicas entre as formas de apreensão da realidade e dos conteúdos escolares. É a partir da interação entre o sujeito e o conhecimento cientificamente elaborado, por meio do mundo digital, que as emoções são geridas nos circuitos de aprendizagem. A tecnologia é capaz de gerar sensações, levando o usuário a "sentir" a História. As literaturas de viagem que deslumbram os alunos em sala de aula, desde um relato de primeira ordem sobre a exploração dos índios na América Espanhola do séc. XVI, a observação de viajantes na cidade do Rio de Janeiro oitocentista, transportam e estabelecem um espaço de experiência entre a realidade e os contextos históricos.

Esse espaço criado é capaz de sedimentar através da experiência e consciência os conteúdos instigados em sala de aula. Logo,

Em uma palavra, trata-se de uma tecnologia intelectual que amplifica a imaginação individual (aumento de inteligência) e permite aos grupos que compartiIhem, negociem e refinem modelos mentais comuns, qualquer que seja a complexidade deles (aumento da inteligência coletiva) (LÉVY, 1999, p. 167).

O produto dessa equação é evidenciado pela capacidade de mobilização dos diferentes conhecimentos individuais, mas que, em grupo, compõem um mosaico próprio e particular elaborado somente por aqueles agentes da comunicação - cada aluno que interage em grupo, a partir de uma ferramenta digital, reconstrói suas totalidades parciais a partir dos seus pontos de vistas e de acordo com seus princípios, elaborados a partir dos conhecimentos trazidos do ambiente social em que vive. Des- 


\section{artigos}

\section{A História no Mundo Digital}

ta forma, as simulações digitais geram outro tipo de conhecimento sendo ele orgânico e socialmente construído ainda que em ambiente virtual.

Retomo a fala de que as tecnologias digitais são ferramentas que geram espaços possíveis para a construção de novas relações sociais com os conteúdos históricos, desde que devidamente formulados e processados. Seguindo esta lógica escolar, para Piaget, segundo Caime, a mais importante tarefa do professor é a proposição de atividades desafiadoras que provoquem desequilíbrios e reequilíbrios sucessivos nos processos de cognição infantil. O conhecimento não é concebido apenas como sendo descoberto espontaneamente pela criança, ou mesmo de forma mecânica pelo professor, mas sim resultado de uma interação com o meio físico, social e simbólico, no qual o sujeito é sempre um elemento ativo que procura apreender os questionamentos do mundo e as interrogações que são provocadas.

Por conta desses processos de desenvolvimento cognitivo, segundo Piaget, a cooperação deve orientar e guiar as elaborações de métodos pedagógicos. “Trata-se do ato de 'operar em comum', isto é, ajustar por meio de novas operações (qualitativas ou métricas) de correspondência, reciprocidade, ou complementaridade, as operações executadas por cada um dos parceiros" (CAIME, 2006, p. 25).

Portanto, as tecnologias podem ser utilizadas como processos de emancipação para o ensino de História apreendido nos diferentes espaços de escolarização, espaços que por sua vez, vão para além da instituição escolar.

Para um melhor aproveitamento desses meandros, é preciso que se esteja consciente dos objetivos e propósitos que se buscam alcançar. Essa estratégia pode ser utilizada como mais um recurso dentro do ensino de História, criando conexões e 


\section{artigos}

\section{Renan Carvalho Wenderrosck}

negociando as distâncias entre professor e aluno (PENNA, 2011). A ação do professor neste momento é aprimorar a ação dos alunos no jogo, provocando e indagando sobre aspectos da ferramenta que, por vezes, podem ter passado despercebidos. O professor é o intermediário entre o conteúdo e os alunos.

Ainda existem muitos desafios pela frente. Como indica Caimi (2006), pensar a formação de professores de História indica questionamento aos modos de formação aos quais os professores têm sido submetidos, implicando colocar em questão o trabalho que tem se desenvolvido nas universidades, nas condições de professores formadores de professores nas licenciaturas em História. Além do mais, o sucateamento da educação, a precarização dos equipamentos tecnológicos nas escolas do ensino básico, a ausência de projetos de atualização da formação docente tendo em vista a valorização do professor-reflexivo-pesquisador, compõem os diferentes desafios para a inclusão das ferramentas digitais na educação.

Ainda que as interfaces ocasionalmente sejam fáceis de se manipular e interagir, é necessário que haja uma composição de esquemas que busquem a conciliação do trabalho docente em relação a esses novos meios de comunicação, elementos estes que já fazem parte do nosso dia a dia.

Além disso, é fundamental que os conhecimentos pedagógicos e os conteúdos específicos estejam alinhados, visto que ambas as esferas são desenvolvidas em sala de aula e na docência. É preciso, enfim, ruir com a concepção de ensino como transmissão de conteúdo, consolidando novas formulações conceituais para o trabalho do docente, a fim de que os objetivos da História sejam alinhados a esses novos tempos.

\section{Conclusão}




\section{artigos}

\section{A História no Mundo Digital}

Tendo em vista o que foi apresentado, é necessário criarmos novas metodologias para o uso das tecnologias nos diferentes espaços de formação. Conscientes de que a tecnologia se faz presente no cotidiano dos alunos, negligenciá-la só contribui em um processo de afastamento do universo dos estudantes.

A Realidade Virtual, os sistemas de virtualização e as ferramentas de Hipertexto estão presentes e fazem parte da era da informação digital, isto é, fazem parte da realidade de professores e estudantes que estão inseridos dentro desse novo mundo.

É essencial repensar os métodos do ensino tradicional que ainda influenciam o ensino de História. Suas características podem ser delimitadas como: ordenação mecânica de fatos em causas e consequências; o uso da repetição como elemento de aprendizagem; ensino eurocêntrico voltado à apreensão dos grandes feitos da humanidade e da história da Nação - heroica e idealizada; sob uma cronologia linear; privilegiando a curta duração e os fatos como elementos isolados.

Como indica Caimi, se tratando do predomínio de um ensino mecânico, basta conversar com um adulto egresso de uma escolarização básica completa para percebermos o quão pouco resta dos conhecimentos estudados nas salas de aulas de História. "Nada mais sobra que fragmentos desconexos de fatos, datas, nomes, muitas vezes sobrepostos aleatoriamente, formando uma grande sopa de letrinhas e datas" (CAIMI, 2006, p. 20).

Busquei, portanto, a partir da interseção da historiografia do Ensino de História e os recursos do mundo digital, traçar os diferentes usos que estes podem contribuir para a superação dos antigos paradigmas históricos. Faz-se necessário pensarmos em possíveis abordagens, assim como cuidados, nos caminhos para um ensino de 


\section{artigos}

\section{Renan Carvalho Wenderrosck}

História mais inclusivo e acessível, compreendendo os desafios educacionais que esses novos tempos apresentam.

Ao construir uma educação capaz de provocar o aluno, inserindo-o na discussão dos problemas históricos, as ferramentas digitais podem definitivamente servir na construção dessa zona compartilhada entre os agentes da relação. Na formulação de uma escola crítica e democrática, o aluno precisa se reconhecer como protagonista, em construção mútua, e não apenas como espectador da história.

Assim, as tecnologias virtuais compõem uma das possibilidades na construção de um espaço amplo e dinâmico no qual se reconhecem nesses equipamentos suas potencialidades em sala de aula. A capacidade de virtualização do conhecimento e sua consequente atualização a partir da interatividade geram novas formulações para as metodologias e práticas docentes, de forma que, ao inserirmos os meios digitais, tratamos de trazer novos elementos na composição do sistema de aprendizagem, por vezes dual: professor/aluno, orador/receptor.

As tecnologias digitais são, consequentemente, apenas instrumentos para a otimização da aprendizagem dos alunos, precisando necessariamente da intermediação do professor na construção do conhecimento histórico e da consciência histórica, visto que somente o professor tem a capilaridade de conhecer os seus alunos e as abordagens necessárias.

Portanto, a partir desse estudo, foi possível observar que as ferramentas digitais não transformam o ensino somente por existirem, considerando-se que conseguimos manter o ensino tradicional usando as tecnologias digitais. A transformação só advém da relação entre o ensino de História reformulado e os espaços virtuais, possibilitando a apreensão e interatividade. 


\section{artigos}

A História no Mundo Digital

Esse circuito gera uma educação voltada à resolução de problemas lógicos, assim como promove a construção da consciência histórica. A tecnologia tem sua tecnicidade com processos e procedimentos de criação informacional, contudo, ao entrar no campo da instrução pedagógica, tem a potencialidade de se transformar, intermediando relações dos campos dos conhecimentos específicos, pedagógicos e sociais, por compor elemento intrínseco da sociedade contemporânea.

Logo, é preciso que o uso dos meios digitais não caia na cultura dos números e da produtividade, onde ganhar é mais importante que aprender. O mundo digital abre espaços para a construção de jogos horizontais nos quais os diferentes sujeitos dependem mutuamente das soluções de problemas e questionamentos que podem ser construídos a partir desses meios.

\section{Referências Bibliográficas:}

ARANHA, Maria Lúcia de Arruda. História da Educação e da Pedagogia. Ed.3. São Paulo: Moderna, 2006.

BITTENCOURT, Circe Fernandes. Reflexões sobre o ensino de História. Estudos Avançados, São Paulo, v.32, n.93, p.127-149, Aug.2018.

BRASIL, Constituição (1934). Título V Capítulo II. Constituição da República dos Estados Unidos do Brasil. Rio de Janeiro, 1934. Disponível em: <http://www.planalto.gov.br/ccivil_03/constituicao/constituicao34.htm>. Acesso em: 04 Agosto 2020.

CAIMI, Flávia Eloisa. Por que os alunos (não) aprendem História? Reflexões sobre ensino, aprendizagem e formação de professores de História. Tempo [online]. 2006, vol.11, n.21, p.17-32.

CHERVEL, A.; COMPÈRE, M.-M. As humanidades no ensino. Educação e Pesquisa. São Paulo, v.25, n.2, p.149-70, jul./dez. 1999. 


\section{artigos}

Renan Carvalho Wenderrosck

FREIRE, Paulo. Pedagogia da autonomia: saberes necessários à prática educativa. São Paulo: Paz e Terra, 1996. - (Coleção Leitura)

FREITAS, Itamar. Fundamentos. teórico-metodológicos para ensino de História. (Anos iniciais). São Cristóvão: Editora da UFS, 2010.

GUIMARÃES, Manoel Salgado. Historiografia e nação no Brasil, 1838-1857. Rio de Janeiro: EdUERJ, 2011.

HOBSBAWM, Eric; RANGER, Terence. A invenção das tradições. Rio de Janeiro: Paz e Terra, 2008.

LDB - Leis de Diretrizes e Bases. Lei $\mathbf{n}^{\circ}$ 9.394/1996. Disponível em: <http://www.planalto.gov.br/ccivil_03/leis/l9394.htm>. Acesso em: 02 Agosto 2020.

LEVY, Pierre. O que é virtual. São Paulo: Editora 34, 1996.

Cibercultura. São Paulo: Editora 34, 1999.

MANOEL, Ivan A. O Ensino de História no Brasil: do Colégio Pedro II aos Parâmetros Curriculares Nacionais (Texto complementar). Disponível em: <http://acervodigital.unesp.br/handle/123456789/46194>. Acesso em: 22 Julho 2020.

MONTEIRO, Ana Maria; PENNA, Fernando. Ensino de História: saberes em lugar de fronteira. Revista Educação \& Realidade, Porto Alegre, v.36, n.1, p.191-211, jan./abr., 2011. Disponível em: <http://www.ufrgs.br/edu realidade>. Acesso em 25 Julho 2020.

OLIVEIRA, Claudemir Gonçalves de. A matriz positivista na educação brasileira: uma análise das portas de entrada no período Republicano. Diálogos Acadêmicos - Revista Eletrônica da faculdade Semar/Unicastelo, v.1, n.1, p.01-17, Edição Out./Jan., 2010.

PERES, Marilen Fagundes; SCHIRMER, Janete; RITTER, Tatiane Souza. O ensino de História no Brasil suas funções e implicações políticas e sociais - Séc. XIX até a atualidade. Revista do Lhiste, Porto Alegre, n.3, vol.2, jul/dez. 2015.

SAVIANI, Dermeval. Escola e democracia: teorias da educação, curvatura da vara, onze teses sobre educação e política. 30ª ed. - Campinas, SP: Autores Associados, 1995.

VARNHAGEN, Francisco Adolfo de. História geral do Brasil: antes de sua separação e independência de Portugal. 2. ed. Rio de Janeiro: E. \& H. Laemmert, 1877. 


\section{artigos}

A História no Mundo Digital

VARNHAGEN, Francisco Adolfo de. História das lutas com os holandeses no Brasil desde 1624 a 1654.1.ed. Lisboa : Typ. de Castro Irmão, 1872. 